\title{
Critiquing Anthropocentric Media Coverage of the COVID-19 Sport "Hiatus"
}

\author{
Samuel M. Clevenger \\ Towson University
}

\author{
Oliver Rick
}

Springfield College

\section{Jacob Bustad \\ Towson University}

\begin{abstract}
This commentary highlights a recent trend of anthropocentrism (a focus on human-centered interests and activities) in the media coverage in the United States and Europe on the disruption of the contemporary sports industry caused by the COVID-19 pandemic. The authors argued that the coverage promotes anthropocentric narratives by framing the pandemic as an external force causing a temporary and unforeseen "hiatus" in the sports industry. As a result, media consumers learn about human interest stories associated with consumer demand and industry adaptation: stories that renormalize, rather than question, the sports industry in its current and hegemonic form. Such media discourses bypass an opportunity to consider the longstanding entanglements of human and nonhuman actors in sporting contexts, rethink sport through environmental and nonhuman perspectives, and, ultimately, advance more progressive, democratic politics. The commentary employs a posthumanist lens to critique the recent anthropocentric media coverage, highlighting the ways in which it reproduces the dualist logic of neoliberal capitalism and deflects attention to the human and nonhuman relations that have always existed in contexts of sport and human physicality.
\end{abstract}

Keywords: anthropocentrism, coronavirus, neoliberalism, uber-sport

COVID-19, the nonhuman coronavirus pathogen that has made an unprecedented impact on global society, dramatically illuminates the intricate human and nonhuman interactions that have always existed in the contexts of sport and everyday life. It is important to recognize from the beginning the human suffering that has occurred during the pandemic. In just the sports world, current and former athletes and notable sports figures have fallen ill or died from complications with the virus, while low-wage workers have lost their jobs due to the cancellation of 
live sporting events. The absence of sports has exacerbated existing social inequalities, including the loss of college scholarships (disproportionately affecting athletes who come from socioeconomically disadvantaged backgrounds), dramatic salary reductions for professional athletes, and unequal support for women's leagues and athletes. At the same time, the pandemic renews attention to the longstanding presence of nonhuman actors in spaces of human activity. A quick search of recent online media articles reveals stories of endangered species thriving in environments deserted by humans, wildlife entering urban areas, and rodents adapting to changes in their food sources. The pathogen has also powerfully reshaped sporting spaces-evidenced in the repurposing of stadiums into field hospitals, morgues, and testing centers-and exposed the role of spectator sporting facilities in emboldening and disseminating deadly pathogens. In short, the arrival of COVID-19 has underscored what we already should have known: that "there are forces that cannot be domesticated ... the Anthropocene is biting back" (Gee \& Anguiano, 2020, para. 2).

Based on the recent media coverage on sport during the pandemic, however, COVID-19 has not inspired a widespread reimagining of the sports model dominating the industry: uber-sport, a term Andrews (2019, p. 10) uses to explicate the "corporatization, commercialization, spectacularization, and celebritization of the traditional sports event" as it exists in 21st-century consumer, neoliberal capitalism. According to Andrews, uber-sport operates with an androcentric, "manufactured sense of masculine self-importance" that privileges the humancentered logic of the capitalist accumulation and "renders it immune to "anything that stands in its way" "(p. 6). Rather than question the sustainability of the model in a historical moment witnessing the consequences of human-led environmental destruction, the recent media coverage has too often normalized the logic of ubersport through a discourse of anthropocentrism: framing the suspension of traditional sporting events as a sudden "crisis" caused by an unforeseen force external to the human activities and interests of the industry. This anthropocentric framing reflects broader, militarized media discourses of a "war" or "fight against" the coronavirus, while allowing coverage of sport to focus on human-centered narratives of consumer demand, industry adaptation, and economic opportunity. The problem is that this anthropocentric framing deflects criticism of the uber-sport industry in its current form and obscures how sporting spaces and bodies have always been enmeshed "in cultural-natural-technological entanglements where anything present is potentially agential, within as well as around us" (Linghede, 2018, p. 573). As we increasingly realize the important interconnections between the frequency of pandemics, climate change, and the environmentally destructive aspects of neoliberal economic development (Wallace, 2016), there is a concomitant need to deconstruct forms of anthropocentrism in public understandings of sport, particularly if the collective goal is to work toward reimagining an industry that can ecologically coexist in a world that "is no longer ours" (Schmidt, 2013, p. 174).

Following Millington and Wilson's (2017, p. 912) call for scholars of sport and physical culture to "consider the associations between active human bodies ... and active non-humans," we analyzed what we believe are the anthropocentric frames within the recent media coverage in the United States and Europe on COVID-19 and the suspension of live sporting events. We concur with Birrell and McDonald (2000, p. 6) that media "[s]tories are always presented within frames, 
and these frames guide and limit public understandings of events and personalities." Though frames are necessary for journalists to "process large amounts of information quickly and routinely," they work through a selection and omission process and shape public opinion in part through privileging certain understandings of reality (Gitlin, 2003, p. 7). The commentary critiques the ways in which anthropocentric frames within media articles implicitly reproduce the neoliberal values of market individualism associated with uber-sport, values that prioritize human interests over environments and nonhuman actors. The critique is informed by theories of posthumanism, what Braidotti $(2013$, p. 2) calls "a qualitative shift in our thinking about what exactly is the basic unit of common reference for our species, our polity and our relationship to the other inhabitants of this planet." At the risk of overgeneralization, posthumanism rejects humanistic dualisms that distinguish human subjects from their nonhuman surroundings, a dualism that has historically powered the ideology and environmentally destructive processes of Western capitalist activities. Posthumanism compels us to complicate our understanding of the interconnections between humans and nonhuman life and rethink sport through the ways in which "people, places, and things forge heterogeneous connections" (Bennett, 2015, p. 226). The point is not to devalue human interests, but rather, to reimagine humanistic objectives through a posthumanist accounting of the complex, enduring relations between people, ecologies, and nonhuman actors.

\section{A Posthumanist Reading of the COVID-19 Suspension of Sport}

A quick survey of the recent coverage on the impact of the COVID-19 pandemic reveals narratives that frame the suspension of the sports industry as a sudden and temporary "hiatus" that will eventually end and ultimately result in the loss of billions of dollars in projected revenue (Radnofsky, Lucey, \& Beaton, 2020, para. 1). Though one columnist contemplated whether "the world of sports will be able to fully recover" (Leitch, 2020, para. 7), most articles seem to parallel broader media speculation on life after the pandemic when nations eventually lift their social distancing restrictions and "go back to normal." Thus, speculation of sports after the pandemic has focused on human-centered changes to operations protocol, behavioral patterns at live events, and a likely decline in fan attendance and interest. Few have suggested that COVID-19 will result in a wholesale reimagining of the global sports industry, with one sport psychologist surmising that "the coronavirus will not be a catalyst for change in the same way as previous moments" (Gardner, 2020, para. 5). When outlets have reported "radical" proposals introduced by professional sports leagues, they have tended to be in the form of adaptations (i.e., rule changes) to preexisting sporting forms.

This "sports-on-hiatus" discourse is deeply problematic because it misunderstands how animals, environments, and nonhuman material entities have always been important actants within sporting, leisure, and active body contexts (Dashper, 2019). First, the discourse advances the dualist logic, born out of the history of Western modernity, which distinguishes human "culture" from nonhuman "nature." The nature-culture dualism, long criticized by historians and scholars 
for its ideological relation to imperialist conquest, environmental degradation, and the subjugation of women and non-Western peoples, empowers the media's framing of COVID-19 as an unforeseen nonhuman shaping force invading sport and other spheres of everyday human life. Such Western dualist logics also undergird the historical ties between anthropocentric definitions of sport and the language of militarism (Butterworth, 2012). This is perhaps part of why recent media coverage of sport during the 1918 influenza pandemic has continued to frame the pathogen through anthropocentric, militarized notions of an invading enemy (Barnhart, 2020). While the 1918 pandemic signifies historical evidence of the longstanding influence of nonhuman actants on the sports world, media outlets of late have revisited the history to remind readers that sports teams and leagues have previously combated infectious pathogens. The message is that human beings and, by extension, the human-centered sport industry have triumphed over infectious pathogens in sport history (albeit with immense humanrelated casualties).

Second, the media coverage exhibits an anthropocentric framing through its focus on stories on human perseverance and economic innovation in response to the pandemic-fueled crisis. Readers learn of attempts by professional organizations to salvage their seasons, with some leagues contemplating whether to continue their season at singular "bubble" locations to simultaneously protect teams and players from possible infection. Other articles celebrate the continuation of preexistent sporting events and note attempts to replicate the experience of spectators at live sporting events through the use of digital audio technologies and life-size dolls. Yet, the point remains that the sports industry, albeit with certain forms of adaptation, "will survive the coronavirus pandemic and go on as before, perhaps with even more celebration and resilience" (Olmsted, 2020, para. 2).

The anthropocentric discourse also allows media outlets to frame emerging economic opportunities as proof of uber-sport's durability in the face of an external threat, subordinating reflection on the sustainability of the industry in its current form. Thus, news outlets have reported on esports organizations and entrepreneurs seeking to capitalize on an increase in home video game consumption and the absence of traditional sporting events. The resulting coverage is a triumphalist spotlighting of industry innovation in the face of adversity and a celebration of how the "gaming and esports scene has risen to the challenge" of supplying consumer demand with new, competitive sporting entertainment (Stedman, 2020, para. 2). The coverage, more critically, trumpets neoliberal, human-centered values of marketplace competitiveness by showcasing how esports organizations, like other major corporations and business sectors in the U.S. economy, have "turned pandemic into profit" (Rushe \& Chalabi, 2020, para. 18).

We believe that the described anthropocentric media coverage is not innocuous, for it bypasses an opportunity created by the COVID-19 pandemic to question the rampant neoliberalization of the sports industry, its corresponding privileging of capitalist accumulation over ecological sustainability, and its failure to recognize the important nonhuman dimensions of everyday life. News organizations like The Guardian in the United Kingdom have published multiple reports centered on the impact of human activities on the nonhuman environment, noting how deforestation, uncontrolled agricultural expansion and agribusiness, and the destruction of wildlife habitats through unchecked capitalist development 
cultivated a "perfect storm" for pandemics (Carrington, 2020, para. 4). This has understandably led some prominent leaders to call for new ways of doing "capitalism differently" in order to prevent future pandemics and create more ecologically sustainable living conditions (Mazzucato, 2020, para. 7). Why are we not seeing a similar questioning of the sustainability of the uber-sport model? How can posthumanism help us to reimagine sport for a post-COVID-19 world?

\section{Implications and Conclusions}

An important consequence of the anthropocentric media discourse previously discussed is that it fosters what Fisher (2009) called capitalist realism: the sense that there is no alternative or structural reimagining of uber-sport in its current neoliberal, commercialized form. Even when journalists and commentators have opined as to the future of sports after the pandemic, few have questioned the return of the industry and our popular, preexisting forms of uber-sport entertainment. This, however, should not blind us to the historical contingencies of sport or allow us to bypass opportunities to rethink sport through progressive, democratic, and nonanthropocentric politics. As Andrews (2019, p. 6) reminded us, sport's "location at the center of US society is not natural, nor even guaranteed. Rather, sports position of prominence requires continuous cultivation by a complex and collusive network of commercially driven parties." Sporting and commercial media organizations operate within that complex, collusive network, and their public narratives often play a vital role in reinforcing the preexisting operations of the industry. This moment of COVID-19 and the suspension of sport reminds us that diligent, critical assessments of industry are perhaps more important than ever before, if we hope to ultimately navigate our way out of the capitalist realism that shapes future visions of the sporting world.

The risk in accepting anthropocentric understandings of sport is that enables organizations in the industry to exacerbate existing economic and social inequalities. We should be wary that the economic and social instability catalyzed by COVID-19 could lead to a state of exception - an "extraordinary decision" taken by governments and governing organizations "to depart from generalized political normativity, to intervene in the logics of ruling and being ruled" (Agamben, 2003, p. 5)-further widening the existing inequality between owners, workers, and athletic laborers in the sports industry. "Exceptional crises justify states of exception" (Chun, 2015, p. 140), and these states of exception can be used to undermine democratic processes and deflect capitalist organizations from public action and criticism. Recently, there have been antidemocratic shifts in sports governance, the adjustment of wage relations with playing and nonplaying workers, and the regulation of fan cultures in Europe, all of which are social issues that have been inflamed, not created, by the pandemic. Rather than perpetuate the neoliberal values that continue to widen social inequalities and fuel environmental destruction, news and media outlets can play a key role in problematizing current owner-labor relations, which necessarily entails dismantling the underlying anthropocentric, profit-driven logic of neoliberal organizations.

With that said, there have been recent developments that demonstrate, at least in localized contexts, that a progressive, ecologically sustainable form of sport is possible. Recently, the British professional football club Forest Green Rovers 
became the first vegan football club and instituted numerous eco-friendly reforms, including the installation of solar panels and organic grass, at the club grounds (Locker, 2019). In 2019, researchers found that SC Freiburg, a German football club, were successful in the consideration of environmental and nonhuman perspectives as they worked to build a new, carbon-neutral stadium. In the course of conceiving and developing the stadium, "environmental concerns were included through a political process that incorporated the interests of a diverse public of human and nonhuman actors" (Bunds, McLeod, Barrett, Newman, \& Koenigstorfer, 2019, p. 6712). Each example, admittedly, occurred in national contexts more conducive to environmental initiatives than the present political context of the United States, and each example does not involve rethinking dominant forms of organized sporting activities. Yet, these examples do demonstrate that industry processes can be mobilized toward posthumanist imperatives that recognize nonhuman and environmental perspectives. There is still work to do in promoting actual nonanthropocentric forms of environmental sustainability, as initiatives can and do devolve into environmental managerialism: a "gesture" toward protecting the environment while privileging and prioritizing humancentered economic growth (Millington \& Wilson, 2017, p. 917). However, this only accentuates the need for researchers and observers of sport to devote careful attention to potential pathways to nonanthropocentric sport and be critical of the ways in which discursive and representational expressions of anthropocentric ubersport stifle the possibility of reimagination.

\section{References}

Agamben, G. (2003). State of exception. Chicago, IL: The University of Chicago Press. Andrews, D.L. (2019). Making sport great again: The uber-sport assemblage, neoliberalism, and the Trump conjuncture. London, UK: Palgrave Macmillan.

Barnhart, T. (2020, May 5). The pandemic and college football: A look back at the 1918 season. Sports Illustrated. Retrieved from https://www.si.com/college/tmg/tonybarnhart/spanish-flu

Bennett, J. (2015). Systems and things: On vital materialism and object-oriented philosophy. In R. Grusin (Ed.), The nonhuman turn (pp. 223-239). Minneapolis, MN: University of Minnesota Press.

Birrell, S., \& McDonald, M.G. (Eds.). (2000). Reading sport: Critical essays on power and representation. Boston, MA: Northeastern University Press.

Braidotti, R. (2013). The Posthuman. Cambridge, UK: Polity Press.

Bunds, K.S., McLeod, C.M., Barrett, M., Newman, J.I., \& Koenigstorfer, J. (2019). The object-oriented politics of stadium sustainability: A case study of SC Freiburg. Sustainability, 11(23), 6712. doi:10.3390/su11236712

Butterworth, M.L. (2012). Militarism and memorializing at the Pro Football Hall of Fame. Communication and Critical/Cultural Studies, 9(3), 241-258. doi:10.1080/14791420. 2012.675438

Carrington, D. (2020, April 27). Halt destruction of nature or suffer even worse pandemics, say world's top scientists. The Guardian. Retrieved from https://www.theguardian. com/world/2020/apr/27/halt-destruction-nature-worse-pandemics-top-scientists

Chun, W.H.K. (2015). Crisis, crisis, crisis; or, the temporality of networks. In R. Grusin (Ed.), The nonhuman turn (pp. 223-239). Minneapolis, MN: University of Minnesota Press. 
Dashper, K. (2019). Moving beyond anthropocentrism in leisure research: Multispecies perspectives. Annals of Leisure Research, 22(2), 133-139. doi:10.1080/11745398. 2018.1478738

Fisher, M. (2009). Capitalist realism: Is there no alternative? Washington, DC: Zer0 Books.

Gardner, H. (2020, April 27). What long-term impacts will the coronavirus have on sports? 'Dr. Fandom' weighs in. USA Today. Retrieved from https://www.usatoday.com/story/ sports/2020/04/27/how-covid-19-pandemic-impact-sports-longterm/3036825001/

Gee, A., \& Anguiano, D. (2020, May 5). We created the Anthropocene, and the Anthropocene is biting back. The Guardian. Retrieved from https://www.theguardian.com/ commentisfree/2020/may/05/we-created-the-anthropocene-and-the-anthropocene-isbiting-back

Gitlin, T. (2003). The whole world is watching: Mass media in the making \& unmaking of the new left. Berkeley, CA: University of California Press.

Leitch, W. (2020, March 15). How will sports recover from this Hiatus? The New York Times. Retrieved from https://www.nytimes.com/2020/03/15/opinion/sports-coron avirus.html

Linghede, E. (2018). The promise of glitching bodies in sport: A posthumanist exploration of an intersex phenomenon. Qualitative Research in Sport, Exercise and Health, 10(5), 570-584. doi:10.1080/2159676X.2018.1479980

Locker, M. (2019, March 2). Meet Forest Green Rovers, the British soccer team that's carbon neutral, vegan, and on a mission. Fast Company. Retrieved from https://www. fastcompany.com/90306520/meet-forest-green-rovers-the-british-soccer-team-thatscarbon-neutral-vegan-and-on-a-mission

Mazzucato, M. (2020, March 18). The Covid-19 crisis is a chance to do capitalism differently. The Guardian. Retrieved from https://www.theguardian.com/commen tisfree/2020/mar/18/the-covid-19-crisis-is-a-chance-to-do-capitalism-differently

Millington, B., \& Wilson, B. (2017). Contested terrain and terrain that contests: Donald Trump, golf's environmental politics, and a challenge to anthropocentrism in Physical Cultural Studies. International Review for the Sociology of Sport, 52(8), 910-923. doi:10.1177/1012690216631541

Olmsted, L. (2020, April 28). When sports return, they will once again play the role of national healer. Los Angeles Times. Retrieved from https://www.latimes.com/opinion/ story/2020-04-28/sports-return-national-healer-coronavirus

Radnofsky, L, Lucey, C., \& Beaton, A. (2020, April 4). Trump makes push for sports to end hiatus 'soon'. The Wall Street Journal. Retrieved from https://www.wsj.com/articles/ trump-makes-push-for-sports-to-end-hiatus-soon-11586040167

Rushe, D., \& Chalabi, M. (2020, April 26). 'Heads we win, tails you lose': How America's rich have turned pandemic into profit. The Guardian. Retrieved from https://www. theguardian.com/world/2020/apr/26/heads-we-win-tails-you-lose-how-americas-richhave-turned-pandemic-into-profit

Schmidt, J. (2013). The empirical falsity of the human subject: New materialism, climate change and the shared critique of artifice. Resilience, 1(3), 174-192. doi:10.1080/ 21693293.2013.837241

Stedman, A. (2020, April 8). As traditional sports grind to a halt, esports offer a way to fill the void. Variety. Retrieved from https://variety.com/2020/digital/features/esportscoronavirus-traditional-sports-league-of-legends-call-of-duty-1234573561/

Wallace, R. (2016). Big farms make big flu: Dispatches on influenza, agribusiness, and the nature of science. New York: New York University Press. 